\title{
In Their Blooming Sixties: Aging as Awakening in Amanda Cross' An Imperfect Spy and The Puzzled Heart
}

\section{Emma Domínguez-Rué}

University of Lleida, Catalunya (Spain)

\section{SUMMARY IN ENGLISH}

The writer and Columbia professor Carolyn Gold Heilbrun (1926-2003) is widely known for her best-selling Kate Fansler mystery novels, published under the pseudonym of Amanda Cross. However, she also authored remarkable pieces of non-fiction in which she asserted her long-standing commitment to feminism, while she also challenged established notions on women and aging and advocated for a reassessment of these negative views. Taking her essays in feminism and literary criticism as a basis and two of her later novels as substantiation to my argument, this paper will try to illustrate the ways in which the aging female characters in her Kate Fansler series became an instrument to make her views on female aging available to a mass audience of women readers. My aim is to reveal the ways in which Heilbrun's highly commercial mystery novels as Amanda Cross were used as a catalyst that informed her feminist principles while vindicating the need to rethink about issues concerning the cultural and literary representations of mature women.

\section{SUMMARY IN CATALAN}

L'escriptora i professora de la Universitat de Columbia Carolyn Gold Heilbrun (1926-2003) és principalment coneguda per les seves novel.les de misteri protagonitzades per Kate Fansler i publicades sota el pseudònim d'Amanda Cross. Tot i això, també ha estat l'autora d'importants obres d'assaig en les quals posa de manifest el seu compromís amb el feminisme, alhora que rebutja conceptes establerts sobre les dones i l'edat i proposa un replantejament d'aquests estereotips negatius. Prenent els seus assajos sobre 
feminisme i crítica literària com a base de la meva argumentació i dos de les seves últimes novel.les per tal de corroborar-la, aquest article prova d'il. lustrar els aspectes en què els personatges femenins de les novel.les de Kate Fansler van esdevenir un instrument per posar les seves idees sobre les dones i l'envelliment a l'abast d'una audiència femenina massiva. Em proposo evidenciar la manera en què les novel.les de misteri d'Amanda Cross constitueixen un element catalitzador que revel.la els prinicipis feministes de l'autora i reivindica la necessitat de replantejar-se presentacions culturals i literàries sobre les dones i l'envelliment.

Keywords: Aging, Cross, Detective, Gender, Heilbrun

Only when a woman ceases the fretful struggle to $b e$ beautiful can she turn her gaze outward, find the beautiful and feed upon it. She can at last transcend the body that was what other people principally valued her for ... this new invisibility, like calm and indifference, is a desirable condition (Greer 1997, p. 266).

The American writer and Columbia professor Carolyn Gold Heilbrun (1926-2003) is more widely known for her best-selling mystery novels, published under the pseudonym of Amanda Cross. However, she also authored remarkable pieces of non-fiction in which she asserted her longstanding commitment to feminism, while she also challenged established notions on women and aging and advocated for a reassessment of these negative views. Works such as Reinventing Womanhood (1979), Writing a Woman's Life (1988), Hamlet's Mother and Other Women (1990) and The Last Gift of Time: Life Beyond Sixty (1997) explore the ways in which womanhood is experienced within a literary and cultural tradition that lacks models of female achievement with which women can identify. Taking her essays in feminism and literary criticism as a basis and two of her later novels as substantiation to my argument, this paper will try to illustrate the ways in which the aging female characters in her Kate Fansler mystery novel series became an instrument to reach a mass audience of readers who might not have read her non-fiction but who were perhaps finding it difficult to reach fulfillment as women under patriarchy. Many critics have noted that the patriarchal view of woman as reproductive and as object of desire relegates mature women to cultural invisibility, especially upon reaching middle age. Despite that, scholars such as Germaine Greer have argued that women's middle years and specially the onset of menopause can bring about a quest for identity unhindered by reproductive aspects, as well as a path towards real autonomy and self-fulfillment 
(Greer 1992, p. 367-368). My aim is to reveal the ways in which Heilbrun's highly commercial mystery novels written as Amanda Cross were used as a catalyst that informed her feminist principles while vindicating the need to rethink about issues concerning the cultural and literary representations of mature women. My essay will concentrate on two of the last novels in the Kate Fansler series: An Imperfect Spy (1995) and The Puzzled Heart (1998). Heilbrun would publish two more novels as Amanda Cross, Honest Doubt (2000) and The Edge of Doom (2002), before she committed suicide in October 2003 by swallowing an overdose of pills and placing a plastic bag over her head. These two novels are to my mind significant because, apart from the highly achieving professor and amateur detective Kate Fansler, Cross presents other remarkable female characters that experience middle age as an awakening and a rebirth rather than as the culturally-inscribed process towards loss and decay, as I will presently illustrate.

According to Jeanne Addison Roberts, Carolyn Heilbrun's works offer scholars an unusual "opportunity to observe both the formulation of feminist theory and the embodiment of theory in fictional creation", as her prolific career as detective novel writer Amanda Cross has run parallel to her academic non-fiction writing. Her views as a feminist theorist, Roberts argues, can be perceived in her novels "as an innocuous-seeming forum for re-education” (Roberts 1995, p. 94). Her search for women's voices and stories in order to provide future generations of women with a model for self-fulfillment through which they can (re-) define their lives is also in many ways exemplified by her own self-(re)creation into her literary alter egos, detective writer Amanda Cross and detective character Kate Fansler:

Amanda Cross could write, in the popular, unimportant form of detective fiction, the destiny she hoped for women, if not exactly, any longer, for herself: the alternate life she wished to inscribe upon the female imagination. ... My hope, of course, is that younger women will imitate her ... in daring to use her security in order to be brave on behalf of other women, and to discover new stories for women (Heilbrun 1988, p. 119, 122).

Heilbrun's non-fiction has extensively argued that women's presence in literary and cultural accounts - if there is indeed such presence - has been limited to serving "as an embodiment or representation of male desire" (Heilbrun 1990, p. 267). As she asserts in Writing a Woman's Life, "anonymity, we have long believed, is the proper condition of woman" (Heilbrun 1988, p. 12). In order to repair women's historical invisibility, Heilbrun proposes that women learn from each other's lives in order to explain their own experience: "as long as women are isolated one from the other, not allowed 
to offer other women the most personal accounts of their lives, they will not be part of any narrative of their own" (Heilbrun 1988, p. 46).

Adding to the interplay between crime novels and life writing, the thought-provoking question that Susan Leonardi asks the reader is whether women, “inscribed as they are in men's language and/or world, ever write their own stories" (Leonardi 1995, p. 115). Since language itself is mediated by patriarchal discourse, the chances to create a truly independent female character seem to be few indeed: as Heilbrun contends in Writing a Woman's Life, "how can women create stories of women's lives if they have only male language with which to do it?" (Heilbrun 1988, p. 40). As Leonardi notes (Leonardi 1995, p. 116), both the author Carolyn Heilbrun/Amanda Cross and her character Kate Fansler are well aware that women crime writers, women professors and women detectives must face the gender inequalities existing both in fiction and in fact. In that respect, Kathleen Klein posits that contemporary women mystery writers are taking a decided step not just as regards the construction of the detective character but also towards the renovation of the genre itself:

\footnotetext{
The woman detective as protagonist is the overwhelming choice of women writers ... Their choice of women as main characters at this particular juncture in history - a moment of feminist and equality awareness - and in the midst of a cultural mass of women-centered writing both in the genres and outside has led women mystery writers to produce not simply conventional novels with differently gendered protagonists but gendered novels with noticeably different agendas. These texts have challenged the formula, the conventions, the structure, and the impact of mystery fiction (Klein 1995, p. 11).
}

In her 1979 work Reinventing Womanhood, Heilbrun had already remarked that existing stereotypes of spinster detectives needed a profound reassessment: sixteen years before her creation of Harriet Furst in An Imperfect Spy, she wrote that "whether they have been left on the shelf or have climbed upon it voluntarily, they turn their solitude into power and their superfluity into freedom" (Heilbrun 1979, p. 96). Harriet Furst provides a good example of this transformation into independence and self-determination, since she embodies an image of a detective that does not conform to the traditional genre's conventions of the character. As Kathleen Klein notes,

The stereotype of the woman detective - the elderly spinster, the naive young woman, the bored housewife - has never been easy to sustain. The contemporary crop of detecting women is not only a critique of those earlier stereotypes and a promise for women's roles in a more open future society 
but also a challenge to the limitations of women's current roles (Klein 1995, p. 12).

Sally Munt's comprehensive volume on feminism and the detective novel Murder by the Book contends that the 1970s and mainly the 1980s witnessed the ascendancy "of a particular type of woman crime writer . . typically white, middle class and often holding a PhD from a well-known university" (Munt 2004, p. 33). According to Munt, the rise of academic detectives and campus murder stories follow the settings of the British and American tradition of crime fiction and use education as a way to social improvement and as a means to solve the mystery. The character of Kate Fansler is an outstanding example among these amateur detectives, which, in Munt's words, embodies the 1970s and 1980s American "bourgeois/liberal privileged form of feminism" that was criticized for providing further advantages to a reduced group of white, middle-class, heterosexual and educated women with "impeccably élite class credentials" (Munt 2004, p. 35). Described in Jean Swanson and Dean James' anthology By a Woman's Hand as "the most literate and literary [sleuth] since Dorothy L. Sayers's Lord Peter Wimsey" (Swanson and James 1994, p. 55), Fansler is not just a university professor but also comes from an upper-class family of considerable wealth and is married to law professor and former Assistant District Attorney Reed Amhearst. Kate's race, social background and professional status, as Anne Cranny-Francis notes, follow the conventions of the genre and to some extent perpetuate this limited version of feminism that Munt refers to, restricted to a privileged few. Further evidence seems to confirm that most scholars in the field regard Kate Fansler as a traditional character, whose role seems to perpetuate patriarchal power rather than subverting it. Neither Priscilla L. Walton and Manina Jones in Detective Agency: Women Rewriting the Hardboiled Tradition (1999) nor Linda Mizejewski in Hardboiled and High Heeled: The Woman Detective in Popular Culture (2004) include the Kate Fansler novels or mention Carolyn Heilbrun in their studies of female characters in hard-boiled popular culture. Although it is obvious that Kate Fansler would not belong to the hardboiled detective tradition, neither author nor character are acknowledged as a precedent for more modern female detectives. Andrew Pepper's The Contemporary American Crime Novel: Race, Ethnicity, Gender, Class (2000)does not discuss any of the Kate Fansler novels or mention Heilbrun at all. The fact that the age factor is left out of the four varieties his study covers is perhaps a reason for this omission. Despite that, Cranny-Francis indeed concedes that the character of Kate Fansler succeeded in creating "an acceptable female professional who can 
begin the process of reconstructing the range of narrative roles available to women" (Cranny-Francis 1990, p. 162-163).

Like her tenured scholar/detective Kate Fansler, Carolyn Heilbrun was Professor of Humanities at Columbia University, and this obvious coincidence between Heilbrun's/Cross' and Fansler's profession has led readers and critics to assume her novels are autobiographical. Although all literary works can be regarded as autobiographical to a greater or lesser extent, Heilbrun repeatedly insisted upon the contrary, but she realized that her criticism of male staff in the academic world that both writer and character inhabited helped to reinforce that assumption. As she reflects in Life Beyond Sixty, "all pompous, self-satisfied, established male professors have similar characteristics; if you have described one, you have described many" (Heilbrun 1997, p. 120-121). The character of Kate Fansler indeed mimicks Heilbrun's career as a pioneering model for women professors at a time when academia was completely male-dominated and women were only starting to access tenured positions. Being a PhD candidate and a professional while mothering three small children in the 1950s, Heilbrun must have felt the anxiety of being torn between motherhood and profession, as well as the pressure of hostile male colleagues. Her article about feminism in literature studies at universities illustrates that conflict:

male fears are palpable... More students are women. The pressure for studying women authors and hiring women professors increases. These male fears are profound, and no less so for being largely unconscious. Meanwhile, the old familiar habits of male dominance and scorn of female interests in the profession make these attitudes appear natural and right (Heilbrun 1985, p. 24).

The novels analyzed here likewise deal with the intolerance of the patriarchal establishment towards the irruption of feminism in academia as well as the increase of women students at universities, especially if they are no longer very young. In An Imperfect Spy, for instance, law professor Blair Whitson provides one among many examples of male discomfort towards the increasing amount of mature women who decide to take up higher education or go back to their studies, mostly after being disappointed by their roles as wives and mothers:

One other thing they've taken to objecting to ... is the number of aging students who are flocking to the law school ... the script goes this way: she's put him through graduate school, provided him with invaluable professional help, and raised the children; now he's decided she isn't suited to his new, more glamorous and successful life. So he marries someone twenty or thirty years younger than he is, and the abandoned wife is totally miserable for a 
year or two, and then one day she discovers that it was the best thing that ever happened to her (Cross 1995, p. 170-171).

The novels examined in this paper - as well as the others in the Kate Fansler series, especially since 1990 - portray female characters that start new lives or reinvent themselves in their later life, even though social constructs on gender do not seem to provide these opportunities for women from middle age onwards. These works of fiction likewise reveal Heilbrun's greater awareness of the negative meanings ascribed to the aging process, and very especially of the "double standard of aging" as expressed by Susan Sontag:

The double standard of aging shows up most brutally in the conventions of sexual feeling, which presuppose a disparity between men and women that operates permanently to women's disadvantage . . . Women become sexually ineligible much earlier than men do . . . For most women, aging means a humiliating process of gradual sexual disqualification. Since women are considered maximally eligible in early youth, after which their sexual value drops steadily, even young women feel themselves in a desperate race against the calendar. They are old as soon as they are no longer very young (Sontag 1997, p. 20).

Sontag's view on the unequal views on aging for men and women is often quoted by Heilbrun, as her non-fiction places a noticeable focus towards "the problems of imagining a positive view of an autonomous woman who is over 50" (Roberts 1995, p. 102). To my mind, the early novels in the Fansler series do not offer many interesting role models among her older female characters: although some of her friends are indeed intelligent and a few even hold positions of power, most of the aging women are shown as weak, domestic and rather contemptible. Jeanne Addison Roberts interestingly perceives "a rage directed specifically and unforgivingly at the failures of the older generation of women" in this period (Roberts 1995, p. 97): an instance of this is the murder of the hateful Mrs. Bradford in The James Joyce Murder (1982), who at the end of the novel is replaced as housewife and mother by a beautiful (much younger) woman. Far from being ironical about such a typically male attitude, Kate seems to be very pleased with the change. In my view, evidence for the author's concern with the experiences of aging women can be found in her non-fiction as well as in her detective novels from the late 1980s onwards, as these present an increasing number of female characters in their middle age (aged fifty or above) as the Kate Fansler series progresses. A Trap for Fools (1989) includes the characters of bestselling writer Penelope Constable and Dean Edna Hoskins, both of them highly achieving women over sixty. In turn, 
the novel that precedes An Imperfect Spy, The Players Come Again (1990), is remarkable both for the number of aging women it presents and for their relevance in the novel: Gabrielle Foxx, Eleanor Goddard, and the three friends Anne Gringold, Nellie Foxx and Dorinda Goddard. These female characters, all in their sixties, become reconciled with their past and find self-fulfillment after having led remarkably selfless lives, precisely at the point in which culture has rendered them invisible as women.

As opposed to the cultural disqualification of women through a process of gradual downgrading and invisibility as they age, Heilbrun explored the possibilities that the onset of middle age can offer to them. Instead of engaging in a frustrating battle against time that can just increase women's sense of loss and self-hatred, Heilbrun asserted that "aging might be gain rather than loss" and that "the impersonation of youth" would be "unlikely to provide the second span of womanhood with meaning and purpose" (Heilbrun 1997, p. 2). She instead urged women "to see this new life as different, as a beginning, as a time requiring the questioning of all previous habits and activities as, inevitably, a time of profound change" (Heilbrun 1997, p. 1-2). In the last decades, many critical voices apart from Heilbrun's have argued against the negative stereotypes associated with gendered aging. In "Toward Another Dimension ...", May Sarton stated that "people do not become less, but more themselves as they grow old ... In old age we have greater freedom than ever before to be our true selves" (Sarton 1997, p. 230-231). Similarly, Roberta Maierhofer coined the term "anocriticism" and thereby defined the female experience of aging as expressed in American texts. In line with Sarton's contention, she considers "female aging as a paradigm of American culture, as aging ... does not bring a loss of identity, but emphasizes difference instead of communality ... and expresses individualism more prominently than in youth" (Maierhofer 2007, p. 24).

As Barbara Frey Waxman puts it in To Live in the Center of the Moment, later life and retirement can offer unexpected possibilities for living new experiences, perhaps more intensely than ever before (Waxman 1997). The creation of Harriet Furst is to my mind an example of defiance of social stereotypes about aging women and a celebration of women's quest for independence and freedom of self in later life. This unusual private eye not only destabilizes the readers' assumptions about female detectives (in Harriet's case, an elderly spinster in the fashion of Agatha Christie's Miss Marple), but also challenges established notions of the accepted roles available to mature women. All the negative stereotypes about aging women are illustrated in the opening scene of An Imperfect Spy, in which an unknown male character silently complains about having to seat next to an elderly woman who has boarded the plane at the very last minute: 
She was old. Old and heavy. Out of shape, with tousled gray hair that needed combing, and styling before that. If he had to have a female companion for the long flight, why not something young, attractive and forthcoming? Old women were the devil. They found an excuse to talk to you, they found some question to ask, and then, before you knew it, you were hearing their life story and were in danger of being bored out of your mind, feigning sleep the only release. Really, it was too bad. She was, at least, on the aisle seat; old women had to pee every goddamn minute (Cross 1995, p. 1-2).

The male passenger is first relieved, then puzzled, and finally suspicious at the fact that the elderly lady is concentrated in her reading and not at all interested in speaking to him, even when he tries to start a conversation. He mentions to her that he is a doctor: a psychiatrist, we assume, given the conclusions of his analysis of the woman's appearance and behavior, which tell the reader more about his own phobias and emotional impairments than about the female character he is describing:

\begin{abstract}
He thought ... that women ought to keep themselves trim as they aged. How could they expect a man to look at them if they let themselves go that way? Her nails were clipped short and she wore no wedding ring. Probably had never had any. Lesbian, perhaps; almost certainly, he then decided. This raised his spirits. No wonder she ignored him . . Passive-aggressive, of course. She knew she couldn't get his attention any other way. And he had fallen for it. That was how that kind of women was; like his mother. They had to put you down, one way or another (Cross 1995, p. 3, 6).
\end{abstract}

His comments on the woman's appearance recall Woodward's statement that "as an older woman, one's success is defined in terms of how closely one approaches the model of the younger woman" (Woodward 1999, p. 159). Not doing her best to conceal her age and therefore disregarding male expectations of what an aged woman should look like is perceived as a lack of decorum on her part, thus illustrating Woodward's view that failure to comply with the strict and confining social codes of dress and behavior expected of aging women is regarded as offensive, not to say obscene (Woodward 1999, p. 150). As Lois Banner similarly reflects,

\footnotetext{
Appearance, more than any other factor, has occasioned the objectification of aging ... It is in this context that aging women especially become double "the other". Trivialized because they are not young, they are also derided because they stand outside of standard conventions of beauty (Banner 1992, p. 15).
}

Jacquelyn Zita has also remarked on the process of invisibilization that patriarchal discourse imposes upon women once they become "too old" 
to be sexually enticing to men: aging females are therefore "gladly left out of the picture ... gladly forgotten, and gladly replaced by younger females ... The crone becomes spectral, an appearance without substance" (Zita 1997 , p. 108). As a former scholar, the female passenger is aware of the social codes that relegate her to invisibility but, as the novel will disclose, she will subvert this cultural notion by using it to her own advantage:

She had walked off into thin air, and no doubt men like this wonderful example had driven her to it ... For who knew better than a woman professor that disappearing into thin air was what most professional men, given their druthers, would have required of her? (Cross 1995, p. 7).

The unknown aging passenger is, the reader later infers, none other than Harriet Furst, the unusual detective character that Cross created in $A n$ Imperfect Spy (1995). Harriet is a retired professor in her late sixties who unexpectedly irrupts in Kate Fansler's life as she is about to undertake a new and challenging project. After Kate's husband Reed Amhearst accepts a proposal by fellow lawyer Blair Whitson to start a law clinic in the conservative Schuyler Law School, Whitson also convinces Kate to join him in lecturing a course on women in literature and law during that semester. Both initiatives are viewed with suspicion by the faculty professors, a group of bigoted and self-satisfied males who see their comfortable positions of power potentially endangered by the subversive intrusion of feminism and equal rights. Harriet meets Kate at a social event and describes herself as "quite without child dependents, quite fancy-free, another definition of widowhood and advancing age" (Cross 1995, p. 17). She surprises Kate by knowing much more about her than she would expect from a complete stranger:

You're less a lady than your mother . . You haven't got children, you don't indulge in social rituals, and you take personal and professional risks. But the risks are all within the confines of the acceptable ... I know you smoke. . I heard you also drink, imbibe caffeine, and consider animal fat essential to human endurance (Cross 1995, p. 18, 38).

Shortly after that first meeting, as Kate and Reed arrive at their apartment one evening, they are shocked to find Harriet sitting in the living room. When asked for an explanation, she answers that she simply got the doorman to open the apartment door for her by pretending to be an aunt of Reed's. Her intention was just to prove that she could rob apartment buildings, since her status as an elderly lady guarantees that nobody will notice her presence: "As an oldish woman, I'm invisible and can go anywhere, like someone in a fairy story ... There's nothing like 
an old woman to bypass anyone, even doormen standing right in front of those signs that say "All visitors must be announced" (Cross 1995, p. 35,39$)$.

The characterization of Harriet Furst is to my mind interestingly linked to the intersections between Heilbrun's biography, her non-fiction work and her detective novels as Amanda Cross. As Kathleen Woodward recalls in "Performing Age, Performing Gender", Heilbrun's long hair tied in a bun and her attire of tunics and baggy trousers responded to a conscious erasure of the markers of a superficial femininity the had always detested: unsurprisingly, "the masquerade of androgynous age became her" (Woodward 2005, p. 288). In relation to this issue, Shulamit Reinharz argues that "in contrast with men, women in general don't begin to challenge the politics of their lives until later ... during their youth women are most valued for their full potential as workers, wives, sex partners and child bearers" (Reinharz 1997, p. 80-81). Harriet reveals that, after a perfectly normal life as a university professor in Boston, she suddenly decided to sell her house, abandon her job and disappear: "I vanished, presumed dead, though not legally, of course" (Cross 1995, p. 40). Upon the sudden realization that her life was no longer fulfilling, the reader assumes, she borrowed her present name from a friend and reinvented herself as a spy in the fashion of John Le Carré's George Smiley, whom she keeps quoting throughout the novel. Harriet's courage in renouncing a comfortable life and her professional prestige in her sixties is certainly atypical and totally opposed to the behavior that would be expected of a woman of her age. She compares her awakening with the curious way in which catalpa trees change their leaves, not gradually but all at the same time:

Boom. All the leaves fell off, and so instead of bowing out gracefully, as one is supposed to do, I just decided to disappear. Like the catalpa trees - all at once ... I decided to become a spy ... And I decided to spy at the Schuyler Law School (Cross 1995, p. 37-39).

Thanks to her intelligence and her excellent organizational skills, Harriet has become the head of the secretarial room at Schuyler, a position that allows her access to all the information she needs to pursue her investigations. Knowing about Kate's commitment to feminism and amateur detecting abilities, Harriet asks Kate to help her in discovering the truth behind the death of Nellie Rosenbusch, the only tenured woman at Schuyler, who was purportedly run over by a truck. Being the only woman professor in an all-male faculty, Nellie's presence had provided her female students with a role model they could identify with and the much-needed encouragement they could never expect of a male academic: 
She [Nellie] was overwhelmed by the women students, who . . . wanted a woman to talk to. It was a strain. They would get angry if she didn't make time for them, assuming her attention as their right, even though they wouldn't dream of making the same assumptions about a male teacher (Cross 1995, p. 99).

As Kate remarks, "women talking to one another are dangerous . . That's why men liked to isolate us in separate houses and make us identify with the men rather than with each other. Women comparing notes frighten men" (Cross 1995, p. 160). Nellie's effort once again evokes Heilbrun's claim that women need to bond and identify with each other in order to find their own path towards self-realization. Both Harriet and Blair Whitson suspect that her death might not have been accidental, since her lonely struggle against the faculty's dominant misogyny was gaining support among her women students and thus she was becoming a threat to her male colleagues. As Blair tells Kate, "Nellie was a thorn in the faculty's side . . . They - the outraged faculty - used everything they could against her, they didn't miss a trick, from sexual harassment to the silent treatment" (Cross 1995, p. 53). Harriet uses the example of the faculty's behavior towards Nellie to warn Kate that the course she intends to teach with Blair will probably be regarded in a similar way, so she should not expect that her task will be an easy one. Although Kate is accustomed to deal with sexist attitudes as a female professor in a predominantly male academic environment, Harriet's support and companionship will prove instrumental to tackle the male bastion at Schuyler:

I'm a gutsy aging woman ... you've never come up against a group of bonded males swollen with mediocrity, enjoying power and set upon defending their turf . . . threatened men are dangerous. They have had power for so long, they have been on the top of the hierarchy for so long, they can't believe that any justice can be involved in their loss of that cozy, high place (Cross 1995 , p. 86-87).

Aside from Nellie Rosenbusch's suspicious death, Kate and Reed learn that Schuyler's closets hide another skeleton, namely that of a member of the faculty who was shot by his wife while he was sleeping. It was known to everyone that Fred Osborne was an alcoholic and that his wife Betty had been a victim of his violence for many years, although none of his colleagues would ever admit to such a thing. The sexist as well as classist views of the faculty upon the subject leave no room for doubt:

Of course he didn't beat her, he was a member of this faculty, not a workingclass thug. She claimed he beat her, of course, but I can tell you the worst he 
did was drink a bit much, and maybe he knocked her around once or twice when he was under the influence, but I'm sure she wasn't battered (Cross 1995, p. 79).

Betty Osborne was under a state of shock after the murder and the battered wife syndrome had not yet been acknowledged by the law, a circumstance that her husband's colleagues predictably used to their advantage to preserve the institution's prestige. The Schuyler faculty members testified that Osborne had not been violent against his wife, so she was charged with murder and her children were taken away from her. Betty was still serving a sentence in a prison on Staten Island, where Reed's law clinic had its potential clients, although she had given up all hopes of ever being treated more fairly by justice and had refused Reed's offer to review her case. Betty had also been Kate's student in graduate school and admired her work on Thomas Hardy, so when she learns that Kate is Reed's wife and that she is lecturing at Schuyler, Betty asks for an interview with her. Those encounters contribute to Betty's gradual awakening, mainly through their discussion of Hardy's Tess of the d'Urbervilles:

Neither Tess nor I seemed to fit into any of the usual categories for women. .. She wasn't pure or impure, she wasn't anything a woman was supposed to be. Except a victim ... But she only seems to be a victim . . . because she does something about her life. She refuses just to be passive (Cross 1995, p. 177).

Nancy Evans observes that "real women are a rare commodity in literature ... So it literally is a shock to see someone like ourselves in the pages of fiction” (Evans 1972, p. 313). Women's identification with a novel or character "through mutual oppression", as Betty identifies with Tess, should "lead to an awakening and then to action" although, as happens with Betty, this is often not the case. She warns that such identification might "quite conveniently be manipulated to become a comfort . . . the reading of women writers can be destructive, pathetically counter-productive if not tempered with critical judgement" (Evans 1972, p. 310-311). That critical judgement that Betty had been lacking until then is triggered by her conversations with Kate, who helps her to overcome self-pity and regain her self-worth, thus contributing to Betty's eventual acceptance of Reed's proposal to review her case. Betty's gradual process towards selfawareness through dialogue with other women - the fictional Tess and the real Kate - illustrates Heilbrun's claim that women need to listen to each other's stories in order to be able to articulate their experience, a view that is here aptly rephrased by Florence Howe: 
In their feminist volumes, Wollstonecraft, Fuller, Woolf, and de Beauvoir ... explain the states of their minds: their perceptions about the social attitudes of men towards women, not only but including intellectual women like themselves: their understanding of the ways in which women learn to be women; their attitudes towards each other. And of course, their volumes are "personal" as well as philosophical or ideological . . trying both to explain their own lives and these forces that control most women's lives ... it is there, in our consciousness about our lives, that the connection between feminism and literature begins. That we learn from lives is, of course, a fundamental assumption of literature and of its teacher-critics (Howe 1972, p. 254-255).

Only in the last chapter of the novel the reader gets to know that Betty is in fact Harriet's daughter. Harriet admits that it was actually she who had convinced Blair to contact her and Reed, in hopes that Betty's admiration for Kate during her student years and Reed's law clinic would contribute to help her daughter regain her self-esteem, ask for a reopening of her case and try to recover her children. Therefore, the reader infers, it was not just the realization about her unfulfilling life but her daughter's plight that encouraged Harriet to die as the woman she used to be and reinvent herself as a completely new person, not just for the sake of her own sanity, but mainly for the benefit of another: "the only power left for women today after they've made a fundamental mistake, is the power to disappear in the old self and reimagine oneself into something, someone, else. That's what I wanted for me and for my daughter" (Cross 1995, p. 201).

In Writing a Woman's Life, as Nancy Miller remarks, Heilbrun herself explained her own reinvention as a crime fiction writer, as she "becomes the biographer of Amanda Cross, telling the story of her own creation as a writer of detective fiction" (Miller 2006). In a clear parallel to Harriet's experience, Heilbrun points out that "few women think of old age and power as compatible ideas for them" (Heilbrun 1988, p. 128-129). As Harriet tells Kate at the end of the novel, the invisibility that culture ascribes to aging women can be in fact used as a new source of autonomy and self-fulfillment: "I've decided to ignore many rules of our society, since, as far as that society knows, I've died and gone to heaven" (Cross 1995 , p. 193). The end of the novel also reinforces Heilbrun's claim that women of all generations are in need of each other for friendship, support and encouragement, in a mutually enriching relationship that is not necessarily restricted to biological motherhood. As Shulamit Reinharz contends,

The severing of bonds may actually reflect a male definition of radical activity, flowing from the boy's breaking the tie with the father as the means of liberation. By contrast, what is radical for women is the ability to bond 
with women, to forge sisterhood with other women rather than separateness (Reinharz 1997, p. 81).

Harriet's courageous rebirth, together with the newly-found power she has used to help her daughter, remind the reader that old age might offer unexpected opportunities for women who find strength in each other and refuse to be defined by cultural views that regard them as non-existent:

Essentially, we are the same - in spirit, you might say. I am what you might be in time, if you play your cards right . . Y You'll have an honorary daughter or two, I hope not in prison, but somewhere, needing you just to exist and encourage ... Somewhere in your psyche you'll be worrying about growing old. Think of me, and remember that it's fun (Cross 1995, p. 204-206).

Harriet Furst reappears in the next Amanda Cross novel, The Puzzled Heart (1998), this time no longer as an amateur spy but as a professional private eye employed by Toni, one of the former secretaries at Schuyler, who has decided to open a detective agency. In her experience working with Harriet, Toni had realized that Harriet's age conferred her extraordinary talents as a private investigator, being "able to move about the world unseen, with the invisibility that age bestows in our society . . Nobody ever sees old women, let alone is able to describe them" (Cross 1998, p. 15, 17). Harriet's invisibility will again be crucial to help Kate Fansler solve the mystery, which this time involves the kidnapping of her husband Reed Amhearst by a fundamentalist Christian group, who threatens to kill him if Kate does not publicly renounce feminism and embrace traditional Christian values. As the kidnappers have instructed Kate not to tell the police, she asks Harriet and Toni to discreetly look into the case and find any connection that might lead them to where Reed is being kept. Kate knows enough of Harriet's detecting abilities to rely on her assurance that "grayhaired women of sufficient age can get in anywhere and are later unidentifiable" (Cross 1998, p. 57), which will result in Reed's eventual release. Reflecting upon Harriet's use of her newly-discovered talents in such an unusual occupation for a woman her age, Kate notices that she had "taken on a new life and a new identity, which seemed to have propelled her wonderfully into the later decades of life" (Cross 1998, p. 14). Only when Toni is attacked and taken to hospital in a very critical state (she will die shortly afterwards) does Kate become aware of Harriet's age for the first time, although her appearance is described more as a consequence of her great distress than as a sign of her chronological age: "Kate had always known her to be in her sixties - or even, by now, beyond - but never before had Harriet looked aged, tired, and fragile" (Cross 1998, p. 136-137). The scene reinforces the idea that age is a cultural construct that has little or 
nothing to do with one's age, but is more related to self-perception and to the degree to which women have internalized or rejected the double standard of aging, as Susan Sontag has observed (Sontag 1997, p. 21). In Life Beyond Sixty, Heilbrun remarked that "the major danger in one's sixties ... is to be trapped in one's body and one's habits, not to recognize those supposedly sedate years as the time to discover new choices and to act upon them" (Heilbrun 1997, p. 35). Aside from Harriet, the novel introduces the character of Kate's intimate friend and confidante Leslie Stewart, an artist who fully developed her talents as a painter in middle age, after she gathered the courage to confront the reality of her unfulfilling life as wife and mother. Just as Harriet decided to die as a professor and be reborn as a detective, Leslie abandoned her old life and revealed her true nature as an artist and as a lesbian: "I've never lived alone. I even went right from marriage to life with Jane. But the loneliness stopped the moment I got out of the marriage . . . throughout my old life . . I was looking for a friend" (Cross 1998, p. 123, 126).

Further substantiation to female stories of success and self-(re) creation in middle age will appear in the next Fansler novel, which presents a different but no less interesting model of professional detective. Honest Doubt (2000) does not actually feature Kate as its main character but is narrated in the first person by its protagonist, licensed private investigator Estelle Aiden Woodhaven, known to everyone as Woody. Woody's unconventionality does not lie in her age (her age is never revealed, but the reader assumes she is somewhere between her mid thirties and late forties) but in her size: unlike similar women detectives in contemporary fiction, she is "fat and nobody's ideal" (Cross 2000, p. 20). Despite her frequent feelings of inadequacy, Woody is also aware of the possibilities that her weight can offer in the same way Harriet knows that being old provides her with special abilities as a detective:

The real talent comes with getting people to talk, relax and talk. And that's where being fat helps. Whether it's because I seem unthreatening, because they can despise me for being fat, or because we like to think of fat people as comforting and nurturing, I'm not sure. Maybe it's because they don't have to bother to flirt with me (Cross 2000, p. 25).

The main plot of the novel is the familiar campus murder (Professor Charles Haycock is poisoned during a party in his house), but this time Kate is not directly involved in it. Although the police is officially looking into the case and are "not that welcoming to private eyes, less so to women", Woody has been hired by the department staff to conduct a parallel investigation. As a university professor acquainted with the academic 
environment and as an amateur detective, Kate is recommended to Woody as a potential source of advice and help. Kate eventually becomes Woody's surrogate older sister and confidante as regards the murder, especially as the ambiguous testimonies and the lack of concluding evidence against any of the suspects increasingly cause Woody to feel unable to solve the case. Despite their recent acquaintance, it is to Kate that Woody turns to for comfort and reassurance: "I sat in Kate's living room spilling my guts. I was feeling humiliated, insecure, and in need of consolation and support" (Cross 2000, p. 160). It is actually Kate who finally suggests the possibility that all the suspects might be involved in having murdered Haycock, in the fashion of Agatha Christie's Murder on the Orient Express.

The novel thus introduces another alternative model of private eye who breaks genre conventions of female detective characters - Woody is no nice elderly spinster, no bored housewife in search of emotions and no attractive (but tough) young professional - while presenting further examples of highly-achieving women whose later lives have symbolized an awakening. In the course of her investigation, Woody becomes acquainted with several intelligent and talented middle-aged women, among which Dean Elaine Kimberly possibly provides the most remarkable example. She replicates Leslie Stewart in the sudden realization that her marriage was unhappy and that neither her job nor her children provided her with the fulfillment that, according to cultural stereotypes, she should expect. Her story also bears a clear resemblance to Harriet's comparison of her awakening with the way catalpa trees drop their leaves, since Elaine suddenly confronted her discontent. Her shock at that realization also involved a feeling of guilt in becoming aware that her real desires had actually nothing to do with established notions of women's happiness:

Something snapped, or perhaps I should say fell into place. I don't want to offer you an extended disquisition on a woman's life, and how it is made to seem that she really wants what she has, how she believes she has what she wants, and, if she has any secret desires, which are against all the forces of her culture, she hardly dares to face them . . . I actually admitted to myself that neither they [her children] nor their company brought me any pleasure (Cross 2000, p. 117-118).

Elaine's surprising decision to tell her children she did not wish to have such close and constant contact with them did not imply a complete estrangement from her family, but actually improved her relationship with them. In Life Beyond Sixty, Heilbrun similarly admitted that she had "found the undiluted presence of young children alternately frustrating and anxiety producing" (Heilbrun 1997, p. 143), while she acknowledges "the pleasure we women feel in conversing with our grown children, and 
in allowing ourselves, from time to time, to think of them as friends" (Heilbrun 1997, p. 185). Elaine's experience also echoes Heilbrun's relief at rejecting certain standards concerning conventional feminine appearance in her sixties: as she writes in Writing a Woman's Life, "it is perhaps in old age, certainly past fifty, that women can stop being female impersonators, can grasp the opportunity to reverse their most cherished principles of 'femininity'" (Heilbrun 1988, p. 126). Elaine explains to Woody that as soon as she admitted to herself what her real desires were and decided to live her life in her own terms, "the college, my children, the need to worry about what I wear vanished" (Cross 2000, p. 119). Heilbrun's account of her own experience in Life Beyond Sixty is very similar to Elaine's, Leslie's and Harriet's fictional stories of midlife awakening:

I understood how privileged Victorian women must have felt when they took off the stays and dresses that inhibited motion, and flexed their bodies, moved their unbound muscles . . . I entered upon a life unimagined previously, of happiness impossible to youth ... I entered into a period of freedom, and only past sixty learned in what freedom consists: to live without a constant, unnoticed stream of anger and resentment (Heilbrun 1997, p. 39).

In her tribute to Carolyn Heilbrun, Susan Gubar acknowledges Heilbrun's claim for the need to find women's voices in order to confer new meanings to women's identity through their constant evolution, also including the later stages of life:

Perhaps at 60, as at 6, we are still "In the Waiting Room," anticipating and dreading the arrival of whatever stage is next, losing a tenuous sense of self while reading and hearing others whose expressions reconfigure a new but just as tenuous self. Reading or hearing each others' writing, we experience the tug of our commonalities, but also our resistance, our need to find ourselves distinctive, unabsorbed, unique, itself an urgency we paradoxically share (Gubar 2006).

As this quote illustrates and as I believe this essay has demonstrated, Heilbrun's detective fiction as well as her non-fiction informed her views on feminism and gendered aging, thus making them available to a mass audience of female readers. The Kate Fansler series allowed the author to re-create herself and rewrite her own autobiography through her detective fiction (Heilbrun 1988, p. 117), while her female characters provided other women with a feminist model of achievement they could follow and offered the female fans of Amanda Cross the chance to reinvent themselves in middle age. As Germaine Greer writes in "Serenity and Power", middle age and menopause might not mark the end of womanhood and 
the beginning of a gradual decline into disempowerment and social invisibility, as the cultural and medical discourses have so far argued. It is perhaps as women cease to fulfill heteromasculine ideals as objects of sexual desire that they can experience womanhood at their fullest:

Let younger people anxiously inquire, let researchers tie themselves in knots with definitions that refuse to stick, the middle-aged woman is about her own business, which is none of theirs. Let the Masters in menopause congregate in luxury hotels all over the world . . the woman herself is too busy to listen. She is climbing her own mountain, in search of her own horizon, after years of being absorbed in the struggles of others . . The climacteric marks the end of apologizing. The chrysalis of conditioning has once and for all to break and the female woman finally to emerge (Greer 1997, p. 272-273).

Heilbrun's battle with her own aging despair and her subsequent suicide inevitably overshadows all the lifelong optimism she had expressed as regards gendered aging. "From Rereading to Reading", published posthumously in 2004, was Heilbrun's Guest Column for PMLA and the last essay she wrote before she committed suicide in 2003 at age 77. By describing her delight in reading science, she proposes to "undertake a radical shift in one's area of intellectual involvement" (Heilbrun 2004, p. 214-215), as the best means to overcome "the dangers of retirement and old age" (Heilbrun 2004, p. 214). Symptomatically, it is the biographies of scientists she turns to in order to find this new fulfillment, thus going back to the reading and rereading of biographies as the means of rewriting the self. Her final quote from e. e. cummings "there's a hell/of a good universe next door; let's go" (Heibrun 2004, p. 217), can therefore be read both as a message of hope or as a ominous harbinger of her suicide. Perhaps, as she always did, she wrote with the attempt to offer future generations of women the energies and the help she could no longer hope for herself.

\section{REFERENCES}

Banner, Lois W. In Full Flower: Ageing, Women, Power and Sexuality. New York: Alfred Knopf, 1992.

Cranny-Francis, Anne. Feminist Fiction: Feminist Uses of Generic Fiction. Cambridge: Polity, 1990.

Cross, Amanda. The James Joyce Murder. New York: Ballantine Books, 1982.

Cross, Amanda. A Trap for Fools. New York: Ballantine Books, 1989.

Cross, Amanda. The Players Come Again. New York: Ballantine Books, 1990.

Cross, Amanda. An Imperfect Spy. New York: Ballantine Books, 1995.

Cross, Amanda. The Puzzled Heart. New York: Ballantine Books, 1998.

Cross, Amanda. Honest Doubt. New York: Ballantine Books, 2000. 
Cross, Amanda. The Edge of Doom. Bath, England and Waterville, ME: Thorndike and Chivers, 2002.

Evans, Nancy Burr. "The Value and Peril for Women of Reading Women Writers." Images of Women in Fiction: Feminist Perspectives. Ed. Susan Koppelman Cornillon. Bowling Green, OH: Bowling Green University Popular Press, 1972. 308-314.

Greer, Germaine. The Change: Women, Aging and the Menopause. New York: Knopf, 1992.

Greer, Germaine. "Serenity and Power." The Other Within Us: Feminist Explorations of Women and Aging. Ed. Marilyn Pearsall. Boulder, CO: Westview, 1997. 253-274.

Gubar, Susan. "Reading in the Waiting Room", in Miller, Nancy K. and Victoria Rosner, eds. The Scholar and Feminist Online 4.2 (2006). Web. 25 June 2012. <http://sfonline.barnard. edu/heilbrun/>.

Heilbrun, Carolyn. "Feminist Criticism: Bringing the Spirit Back to English Studies." The New Feminist Criticism: Essays on Women, Literature, and Theory. Ed. Elaine Showalter. New York: Pantheon Books, 1985. 21-28.

Heilbrun, Carolyn. Reinventing Womanhood. New York and London: Norton, 1979.

Heilbrun, Carolyn. Writing a Woman's Life. New York: Ballantine Books, 1988.

Heilbrun, Carolyn. Hamlet's Mother and Other Women. New York: Ballantine Books, 1990.

Heilbrun, Carolyn. The Last Gift of Time: Life Beyond Sixty. New York: Ballantine Books, 1997.

Heilbrun, Carolyn. "Guest Column: From Rereading to Reading." PMLA 119.2 (2004): 211-217.

Howe, Florence. "Feminism and Literature." Images of Women in Fiction: Feminist Perspectives. Ed. Susan Koppelman Cornillon. Bowling Green, OH: Bowling Green University Popular Press, 1972. 253-277.

Klein, Kathleen Gregory. "Women Times Women Times Women." Women Times Three: Writers, Detectives, Readers. Ed. Kathleen G. Klein. Bowling Green, OH: Bowling Green University Popular Press, 1995. 3-13.

Leonardi, Susan J., "Murders Academic: Women Professors and Crimes of Gender." Feminism in Women's Detective Fiction. Ed. Glenwood Irons. Toronto: University of Toronto Press, 1995. 112-126.

Maierhofer, Roberta. "An Anocritical Reading of American Culture: The Old Woman as the New American Hero." Journal of Aging, Humanities and the Arts (2007): 23 - 33.

Mizejewski, Linda. Hardboiled and High Heeled: The Woman Detective in Popular Culture. New York and London: Routledge, 2004.

Miller, Nancy K. "The Age Difference." The Scholar and Feminist Online 4.2 (2006). Web. 25 June 2012. <http://sfonline.barnard.edu/heilbrun/>.

Munt, Sally R. Murder by the Book? Feminism and the Crime Novel. New York and London: Routledge, 2004.

Pepper, Andrew. The Contemporary American Crime Novel: Race, Ethnicity, Gender, Class. Edinburgh: Edinburgh University Press, 2000.

Reinharz, Shulamit. "Friends or Foes: Gerontological and Feminist Theory." The Other Within Us: Feminist Explorations of Women and Aging. Ed. Marilyn Pearsall. Boulder, CO: Westview, 1997. 73-94.

Roberts, Jeanne Addison. "Feminist Murder: Amanda Cross reinvents womanhood." Feminism in Women's Detective Fiction. Ed. Glenwood Irons. Toronto: University of Toronto Press, 1995. 94-111.

Sarton, May. "Toward Another Dimension ..." The Other Within Us: Feminist Explorations of Women and Aging. Ed. Marilyn Pearsall. Boulder, CO: Westview, 1997. 229-232.

Sontag, Susan. "The Double Standard of Aging." The Other Within Us: Feminist Explorations of Women and Aging. Ed. Marilyn Pearsall. Boulder, CO: Westview, 1997. 19-24.

Swanson, Jean and Dean James, Eds. By a Woman's Hand: A Guide to Mystery Fiction by Women. New York: Berkeley Books, 1994. 
Walton, Priscilla L. and Manina Jones. Detective Agency: Women Rewriting the Hardboiled Tradition. Berkeley, CA: University of California Press, 1999.

Waxman, Barbara Frey. To Live in the Center of the Moment: Literary Autobiographies of Aging. Charlottesville: University of Virginia Press, 1997.

Woodward, Kathleen, Ed. Aging and its Discontents: Freud and Other Fictions. Bloomington, IN: Indiana University Press, 1999.

Woodward, Kathleen. "Performing Age, Performing Gender: The Feminist Legacy of Carolyn Heilbrun." Tulsa Studies in Women's Literature. 24.2 (2005): 283-290.

Zita, Jacquelyn R. "Heresy in the Female Body: The Rhetorics of Menopause". The Other Within Us: Feminist Explorations of Women and Aging. Ed. Marilyn Pearsall. Boulder, CO: Westview, 1997. 95-112.

\section{BIOGRAPHICAL NOTE}

Emma Domínguez-Rué graduated in English at the University of Lleida (Catalunya, Spain) and studied an MA in English Literature at Swansea University (UK). She specialized in female invalidism in the fiction of Ellen Glasgow and read her PhD dissertation at the University of Lleida (Spain) in 2005. Her dissertation was published in 2011 with the title Of Lovely Tyrants and Invisible Women: Invalidism as Metaphor in the Fiction of Ellen Glasgow (Berlin: Logos Verlag). Aside from American Studies, she has also worked on Victorian and Gothic fiction under a feminist perspective. She is currently teaching in the Department of English at the University of Lleida and she is member of ENAS, a European research network working on aging studies. 